\title{
EFEKTIVITAS PROJECT BASED LEARNING TERHADAP KEMAMPUAN PEMECAHAN MASALAH DAN BERPIKIR KRITIS MAHASISWA
}

\section{THE EFFECTIVENESS OF PROJECT BASED LEARNING IN TERM OF THE STUDENTS' ABILITIES PROBLEM SOLVING AND CRITICAL THINKING}

\author{
Edi Susanto ${ }^{*}$, Agus Susanta2, Rusdi3, \\ 1,3 Pendidikan Matematika, FKIP, Universitas Bengkulu, Jln.WR Suparatman, 38371, Indonesia \\ 2 S-2 Pendidikan Dasar, FKIP, Universitas Bengkulu, Jln.WR Suparatman, 38371, Indonesia \\ *e-mail: edisusanto@unib.ac.id
}

\begin{abstract}
ABSTRAK
Penelitian ini bertujuan untuk mengkaji keefektifan dari model project-based learning (PjBL) ditinjau dari kemampuan pemecahan masalah dan berpikir kritis mahasiswa pada matakuliah statistika dasar. Jenis penelitian ini adalah penelitian quasi eksperimen. Populasi dalam penelitian ini adalah seluruh mahasiswa program studi pendidikan matematika angkatan 2019 yang terdiri dari dua kelas dengan jumlah 64 orang. Sampel dalam penelitian ini adalah kelas IIA sebagai kelas eksperimen dengan 34 mahasiswa. Sedangkan kelas kontrol kelas IIb dengan jumlah 30 orang. Instrumen penelitian terdiri dari lembar tes dan angket respon mahasiswa. Instrumen tes berupa soal untuk mengukur kemampuan pemecahan masalah dan berpikir kritis. Analisis data menggunakan: (1) uji prasyarat yang terdiri dari uji normalitas dan uji homogenitas, (2) uji hipotesis yang terdiri dari uji Anova dan uji statistik multivariate analisis varian (Manova). Hasil penelitian menunjukkan bahwa model PjBL efektif dalam ditinjau kemampuan pemecahan masalah dan kemampuan berpikir kritis mahasiswa dalam pembelajaran statistik dasar.
\end{abstract}

Kata Kunci: PjBL, pemecahan masalah, berpikir kritis

\section{ABSTRACT}

This study aimed to investigate the effectiveness of the Project-Based Learning Model (PjBL) in terms of students' ability of problem solving and critical thinking on basic statistics courses. This type of research was a quasi experiment. The population in this study were all students of the mathematics education study program first enroll in year 2019 consisting of two classes with a total of 64 students. The sample in this study was class IIA as an experimental class consisted of 34 students, while the control class was class IIB consisted of 30 students. The instruments of the research were test and questionare of students' response. Test instruments were used to measure students' problem solving and critical thinking skills. Data analysis used (1) prerequisite test that consised of normality and homogeneity tests, (2) hypothesis testing that consisted of Anova test and multivariate variance analysis (Manova). The results showed that the PjBL model was effective in term of students' problem solving abilities and critical thinking skills in learning on basic statistics course

Keywords: PjBL, problem solving, critical thinking 


\section{PENDAHULUAN}

Luaran lulusan dari mahasiswa program studi pendidikan matematika adalah sebagai guru matematika di tingkat sekolah menengah. Hal ini menuntut mahasiswa untuk menguasai matematika secara keseluruhan salah satunya di bidang kompetensi profesionalisme. Hal ini dikarenakan matematika merupakan pelajaran yang memiliki peranan penting. Selajalan dengan hal tersebut, Pembelajaran matematika merupakan salah satu unsur penting dalam pengembangan pendidikan di Indonesia [1].

Selain itu, sebagai calon guru matematika mahasiswa hendaknya dapat mengembangkan keterampilan pemecahan masalah dan kemampuan berpikir kritis sehingga mampu mengkaitkan semua konsep matematika dalam menyelesaikan masalah pada setiap pembelajaran. Hal ini sejalan dengan pendapat Sabandar menyebutkan bahwa tujuan pembelajaran di sekolah salah satunya agar siswa memiliki kemampuan pemecahan masalah matematika [2].

Kegiatan pembelajaran matematika bertujuan untuk meningkatkan kemampuan dalam berpikir logis, keterampilan memecahkan masalah, serta kemampuan berpikir abstrak. Pendapat ini menunjukkan bahwa pentingnya bagi mahasiswa sebagai calon guru untuk menumbuhkembangkan keterampilan pemecahan masalah agar nantinya dapat mendesain pembelajaran untuk siswa dalam mencapai tujuan pembelajaran. Selain itu, adanya tuntutan guru untuk menanamkan dan mengembangkan keterampilan siswa dalam memecahkan masalah mengharuskan mahasiswa menguasai kemampuan tersebut di perkuliahan [3].
Menurut Schroeder \& Lester "problem solving is also important because it can serve as a vehicle for learning new mathematical ideas and skills" [4]. Pernyatan tersebut menjelaskan bahwa pemecahan masalah adalah hal yang sangat penting karena pemecahan masalah merupakan sarana mempelajari ide matematika dan keterampilan matematika. Pentingnya kemampuan pemecahan masalah dan berpikir secara kritis untuk difokuskan pada pembelajaran di perkuliahan dikarenakan tuntutan lulusan perguran tinggi dalam menghadapi persaingan dalam dunia kerja. Dalam memperoleh pekerjaan lulusan harus memiliki kemampuan dan cara berpikir yang kritis dan harus memiliki kompetensi yang mumpun.

Kenyataan menunjukkan bahwa ditinjau dari kemampuan pemecahan masalah mahasiswa masih perlu ditingkatkan. Salah satunya di Program studi matematika FKIP UNIB. sebagai contoh, data hasil ujian semester tengah pada mata kuliah statistik dasar mahasiswa program studi pendidikan matematika tahun ajaran 2018/2019. Gambar 1 merupakan Salah satu soal yang mengukur kemampuan pemecahan masalah.

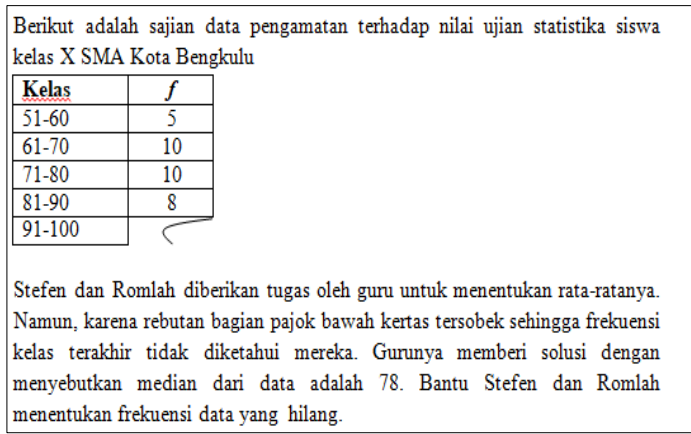

Gambar 1.

Soal Tes Pemecahan Masalah

Berdasarkan analisis dari hasil tes terhadap 32 orang mahasiswa Program Studi Pendidikan Matematika kelas B 
angkatan 2018 menunjukkan bahwa sebagian mahasiswa hanya mampu memahami masalah. Hasil analisis jawaban mahasiswa terhadap tes disajikan pada Tabel 1.

Tabel 1.

Hasil Analis Tes Pra Penelitian

\begin{tabular}{|l|c|c|}
\hline $\begin{array}{c}\text { Tahapan } \\
\text { Pemecahan } \\
\text { Masalah }\end{array}$ & $\begin{array}{c}\text { Jumlah } \\
\text { Benar }\end{array}$ & $\begin{array}{c}\text { Persentase } \\
\text { (\%) }\end{array}$ \\
\hline $\begin{array}{l}\text { Memahami } \\
\text { permasalahan }\end{array}$ & 20 & 62,50 \\
\hline $\begin{array}{l}\text { Menyusun } \\
\text { rencana } \\
\text { strategi }\end{array}$ & 12 & 37,50 \\
\hline $\begin{array}{l}\text { Melaksanakan } \\
\text { rencana }\end{array}$ & 10 & 31,25 \\
\hline Mengevaluasi & 4 & 12,50 \\
\hline
\end{tabular}

Hasil analisis pada tabel di atas menunjukkan bahwa pada mahasiswa belum mampu menyusun rencana strategi dalam menyelesaikan permasalahan. Hal ini menunjukkan bahwa mahasiswa masih kesulitan menentukan formula atau konsep apa yang digunakan dalam menyelesaikan permasalahan. Salah satu faktor penyebabnya berdasarkan hasil diskusi dengan mahasiswa adalah belum terbiasanya mahasiswa mengerjakan bentuk soal yang demikian. Soal yang umum diselesaikan ketika jenjang SMA adalah soal yang rutin dengan menggunakan formula dasar.

Upaya yang dapat dilakukan untuk meningkatkan kemampuan mahasiswa dalam melakukan pemecahan masalah dan berpikir secara kritis adalah dengan mendesain pembelajaran di kelas. Penggunaan model pembelajaran yang memfasilitasi mahasiswa untuk dapat mengonstruksi pemahamannya sendiri dalam pembelajaran matematika di tingkat perguruan tinggi. Pembelajaran dapat dilakukan dengan melibatkan mahasiswa secara langsung untuk mengembangkan kemampuan tersebut salah satunya adalah model project based learning (PjBL). Model PjBL memfasilitasi peserta didik untuk membuat produk dalam rangka menyelesaikan permasalahan kehidupan nyata. Proyek pembuatan produk dapat dilakukan secara individu maupun kelompok.

Model project based learning dinilai cocok dengan karakteristik peserta didik pada tingkat mahasiswa karena pelaksanaan proyek menuntut tanggungjawab yang tinggi. Peserta didik membutuhkan keterampilan berpikir tingkat tinggi untuk dapat menghasilkan produk yang dapat digunakan untuk menyelesaikan permasalahan kehidupan nyata. Dalam pelaksanaan proyek peserta didik dituntut untuk mampu memahami konsep dengan baik sekaligus menghasilkan produk yang berhubungan dengan konsep tersebut. Dalam PjBL, Peserta didik dimungkinkan untuk memilih sendiri proyek yang akan dikerjakan, selain itu kegiatan pembelajaran diatur untuk belajar aktif dan kerja sama tim [5].

Beberapa hasil kajian empiris yang menyebutkan bahwa model project based learning efektif dalam meningkatkan hasil belajar. Hasil penelitian Filcik, Bosch, Pederson, \& Haugen yang menunjukkan bahwa model pembelajaran tersebut efektif ditinjau dari aspek pengetahuan konseptual [6]. Hasil penelitian yang dilakukan oleh Ozdemir dan Beres menyebutkan bahwa model pembelajaran berbasis project efektif dalam meningkatkan hasil belajar matematika peserta didik [7] [8].

Berdasarkan uraian tersebut maka peneliti ingin melakukan penelitian yang menggunakan model project based learning. Penerapan model PjBL dilaksanakan untuk menumbuh kembangkan kemapuan pemecahan 
masalah dan kemampuan berpikir kritis mahasiswa pendidikan matematika FKIP UNIB pada matakuliah statistika dasar. Tahapan PjBL yang digunakan yaitu: (1) fase pra proyek, (2) identifikasi masalah, (3) Desain Proyek, (4) Mengumpulkan dan mengolah informasi, (5) menyusun draft produk, (6) menilai produk, (7) mempresentasi produk

\section{METODE PENELITIAN}

Penelitian ini merupakan penelitian eksprimen semu (quasi ekperimen). Penelitian ini bertujuan untuk menguji hipotesis yang dirancang dengan dua kelas yaitu kelas ekperimen dan kelas kontrol. Variabel terikat dalam penelitian ini terdiri dari dua, yaitu: kemampuan pemecahan masalah dan berpikir kritis mahasiswa. Sedangkan variabel bebas model project based learning.

Populasi dalam penelitian ini adalah seluruh mahasiswa Program Studi Pendidikan Matematika Jurusan Pendidikan MIPA FKIP Universitas Bengkulu angkatan 2019 pada semester ganjil tahun akademik 2019/2020. Jumlah populasi penelitian terdiri dari dua kelas dengan total sebanyak 64 orang. Pemilihan mahasiswa angkatan 2019 sebagai sasaran penelitian dikarenakan mengambil mata kuliah statistik. Selain itu, angkatan 2019 merupakan angkatan baru yang menyesuaikan transisi pembelajaran dari SMA ke perguruan tinggi.

Teknik pemilihan sampel menggunakan metode sensus dimana semua anggota populasi dijadikan sampel penelitian. Metode sensus didefinisikan sebagai teknik penentuan sampel bila semua anggota populasi digunakan sebagai sampel [9]. Sampel terdiri dari dua kelas, yaitu mahasiswa angkatan 2019 kelas A dengan jumlah mahasiswa 34 orang dan Kelas B sebanyak 30 orang. Pemilihan sampel untuk pemberian perlakuan pembelajaran dengan $\mathrm{PjBL}$ dipilih secara acak atau random. Satu kelas dipilih sebagai kelas eksperimen (pembelajaran model PjBL) dan kelas lainnya sebagai kelas kontrol .

Desain dalam penelitian ini dengan desain kelompok kontrol pretespostest seperti pada gambar 2

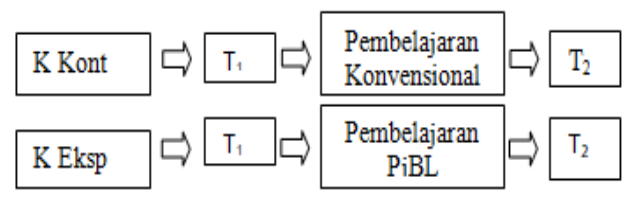

Gambar 2. Rancangan penelitian

Teknik pengumpulan data dalam penelitian ini terdiri dari dua, yaitu: teknik tes dan non-tes. Teknik tes terdiri dari tes yang mengukur kemampuan pemecahan masalah dan berpikir kritis berbentuk uraian. Sedangkan, non tes berupa lembar observasi aktivias mahasiswa dalam pembelajaran ststitika dasar. Pengumpulan data dilakukan secara langsung oleh peneliti dengan melaksanakan pretest dan posttest dalam penelitian.

Instrumen tes dalam penelitian ini berupa tes dan kemampuan pemecahan masalah dan berpikir kritis. Pos-test dilaksanakan untuk mengetahui kemampuan pemecahan masalah dan kamampuan berpikir kritis mahsiswa dari setelah diterapkan pembelajaran dengan PjBL. Tes kemampuan masalah berdasarkan indikator pemecahan masalah dengan tahapan polya, yaitu: (1) memahami masalah, merencanakan penyelesaian, melaksanakan rencana, (4) memeriksa kembali. Sedangkan kemampuan berpikir kritis mengacu pada Facione yang terdiri dari, (1) mengidentifikasi dan menjastifikasi konsep, (2) menggeneralisasi, (3) menganalisis 
algoritma, (4) memecahkan masalah [10].

Data yang diperoleh dari penelitian dianalisis menggunakan beberapa metode yaitu: (1) uji prasyarat yang terdiri dari: uji normalitas dan uji Homogenitas. (2) uji hipotesis dengan uji-F dengan Anova (melihat pengaruh masing-masing taraf perlakuan) dan Manova (melihat pengaruh secara keseluruhan). Analasis data menggunakan program SPSS.

\section{HASIL DAN PEMBAHASAN}

a. Deskripsi Data Hasil Penelitian

Sebelum dilakukan proses pembelajaran pada kelas eksperimen dan kelas kontrol, terlebih dahulu diberikan tes yang bertujuan untuk mengukur kemampuan awal pemecahan masalah dan berpikir kritis mahasiswa. Hasil pretest kemampuan pemecahan masalah dan berpikir kritis pada kelas eksperimen dan kelas kontrol disajikan pada Tabel 2.

Tabel 2.

Deskripsi rata-rata hasil pretest

\begin{tabular}{|l|l|c|c|}
\hline Kemampuan & Kelas & Siswa & Nilai \\
\hline Pemecahan & Eks & 34 & 38,97 \\
\cline { 2 - 4 } Masalah & Kont & 30 & 37,10 \\
\hline Berpikir & Eks & 34 & 40,56 \\
\cline { 2 - 4 } Kritis & Kont & 30 & 39,07 \\
\hline \multicolumn{4}{|l|}{ Setelah dilakukan proses }
\end{tabular}

pembelajaran di kelas eksperimen (model PjBL) dan kontrol (ekspisitori) dilakukan postets. Postest terdiri dari, yaitu tes mengukur kemampuan pemecahan masalah dan kemampuan berpikir kritis. Gambaran hasil tes disajikan pada Tabel 3.

Tabel 3.

Deskripsi hasil posttest

\begin{tabular}{|c|c|c|c|}
\hline Kemampuan & Kelas & Sisw & Skor \\
\hline \multirow{2}{*}{$\begin{array}{l}\text { Pemecahan } \\
\text { Masalah }\end{array}$} & Eks & 34 & 84,19 \\
\hline & Kont & 30 & 68,54 \\
\hline \multirow{2}{*}{$\begin{array}{l}\text { Berpikir } \\
\text { Kritis }\end{array}$} & Eks & 34 & 83,33 \\
\hline & Kont & 30 & 67,47 \\
\hline
\end{tabular}

Tabel 3 menunjukkan bahwa secara rata-rata kemampuan pemecahan masalah dan berpikir kritisi mahasiswa yang diberikan pembelajaran PjBL lebih tinggi dari kelas dengan pembelajaran ekspisitori. b. Deskripsi hasil pengujian prasyarat

$$
\text { Uji normalitas dengan }
$$
menggunakan program SPSS dengan uji Kolmogorov-Smirnov. Kriteria pengujian normalitas adalah jika $Z_{\text {hitung }}$ $>0,05(\alpha)$ maka $\mathrm{H}_{0}$ diterima. Hasil pengujian seperti pada tabel 4 .

Tabel 4.

Hasil Uji normalitas

\begin{tabular}{|l|c|c|c|c|}
\hline \multicolumn{1}{|c|}{ Data } & Kelas & $\begin{array}{c}\text { Sta- } \\
\text { tistic }\end{array}$ & df & Sig. \\
\hline $\begin{array}{l}\text { Pemecahan } \\
\text { Masalah }\end{array}$ & Eks & 0,150 & 34 & 0,200 \\
\cline { 2 - 5 } $\begin{array}{l}\text { Berpikir } \\
\text { Kritis }\end{array}$ & Eks & 0,162 & 30 & 0,140 \\
\cline { 2 - 5 } & Kont & 0,152 & 30 & 0,200 \\
\hline
\end{tabular}

Tabel 4 di atas menunjukkan bahwa data kemampuan pemecahan masalah dan berpikir kritis pada setiap kelas mempunyai taraf signifikan lebih dari $0,05(\alpha)$. Berdasarkan kriteria pengujian normalitas maka setiap data kemampuan pemecahan masalah dan berpikir kritis berdistribusi normal.

Selanjutnya, data dilakukan pengujian homogenitas. Pengujian menggunakan uji Anova satu jalur dengan kriteria pengujian data memenuhi homogenitas jika signifikansi pada uji levene lebih dari $\alpha(0,05)$. Hasil analisis ditunjukkan tabel 5 .

Tabel 5.

Uji Homegenitas

\begin{tabular}{|c|c|c|c|}
\hline $\begin{array}{c}\text { Levene } \\
\text { Statistic }\end{array}$ & df1 & df2 & Sig. \\
\hline 0,362 & 1 & 63 & 0,781 \\
\hline 0,230 & 1 & 63 & 0,079 \\
\hline Berdasarkan & \multicolumn{3}{|c|}{ data hasil uji }
\end{tabular}

homogenitas di atas diketahui bahwa nilai signifikansi lebih dari 0,05 (nilai $\alpha)$. Hal ini berarti data tes kemampuan pemecahan masalah dan kemampuan 
berpikir kritis matematika siswa setiap kelas penelitian adalah berdistribusi homogen.

c. Hasil Pengujian Hipotesis

a. Pengaruh PjBL terhadap kemampuan pemecahan masalah

Pengujian hipotesis yang akan diuji dengan menggunakan analisis statistik Anova. Pengujian hipotesis dilakukan untuk mengetahui apakah ada pengaruh model PjBL yang diberikan terhadap kemampuan pecahan masalah mahasiswa dalam pembelajaran statistika. Hasil uji Anova diperoleh nilai $F$ sebesar 15,56 dengan tingkat signifikansi sebesar 0,00 . Sehingga hipotesis diterima. Hal ini berarti terdapat pengaruh model pembelajaran yang diberikan terhadap kemampuan pemecahan masalah.

b. Pengaruh PjBL terhadap kemampuan berpikir kritis

Pengujian hipotesis selanjutnya untuk mengetahui apakah ada pengaruh model PjBL yang diberikan terhadap kemampuan berpikir kritis mahasiswa dalam pembelajaran statistika dasar. Kriteria pengujian: Jika nilai probabilitas (sig.) kurang dari $\alpha=$ 0,05 , maka hipotesis $\mathrm{H}_{0}$ ditolak. Hasil uji Anova diperoleh nilai $F$ sebesar 20,88 dengan tingkat signifikansi sebesar 0,00. Sehingga hipotesis diterima. Sehingga terdapat pengaruh model project based learning terhadap kemampuan berpikir kritis mahasiswa dalam pembelajaran statistika

c. Pengaruh PjBL terhadap Pemecahan Masalah dan Berpikir Kritis

Untuk menguji pengaruh secara bersama-sama menggunakan uji statistik Manova. Kriteria pengujian yang digunakan adalah jika nilai probabilitas (sig.) kurang dari $\alpha=0,05$, maka hipotesis $\mathrm{H}_{0}$ ditolak dan jika (sig.) lebih dari $\alpha=0,05$ maka hipotesis $\mathrm{H}_{0}$ diterima dapun hasil uji Manova seperti pada tabel berikut
Tabel 6.

Tests of Between-Subjects Effects

\begin{tabular}{|c|r|r|c|c|}
\hline Source & df & F & Sig. & $\begin{array}{c}\text { Partial } \\
\text { Eta } \\
\text { Squared }\end{array}$ \\
\hline Intercept & 1 & $\begin{array}{r}7525, \\
469\end{array}$ &, 000 &, 995 \\
\hline kelas & 1 & $\begin{array}{r}24,88 \\
6\end{array}$ &, 006 &, 402 \\
\hline Error & 37 & & & \\
\hline
\end{tabular}

Tabel di atas menunjukkan nilai signifikan sebesar $0,006<\alpha=0,05$. Sehingga hipotesis diterima, Hal ini berarti terdapat pengaruh model $P j B L$ terhadap kemampuan pemecahan masalah dan berpikir kritis mahasiswa dalam pembelajaran statistika.

Hasil penelitian menunjukkan bahwa kemampuan pemecahan masalah dan berpikir kritis mahasiswa yang diberikan pembelajaran $\mathrm{PjBL}$ lebih baik dari pembelajaran ekspisitori. Hal ini ditunjukkan dari perbandingan nilai rata-rata pada kelas eksperimen lebih tinggi dibandingkan kelas kontrol. Tahapan-tahapan dalam PjBL dapat menunjang mahasiswa dalam mengkontruksikan kemampuan berpikir, khususnya pada tahapan mengumpulkan dan mengolah informasi. Perbandingan kemampuan pemecahan masalah dan berpikir kritis antara kelas eksperimen dan kontrol seperti gambar 2 .

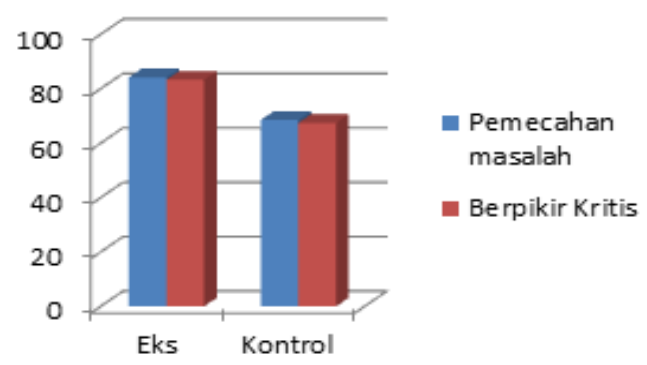

Gambar 2.

Perbandingan kemampuan

pemecahan masalah dan kritis mahasiswa

Berdasarkan analisis statistik Anova dan Manova diketahui bahwa 
model PjBL lebih efektif dibandingkan model ekspisitori dalam meningkatkan kemampuan pemecahan masalah dan berpikir kritis. Hasil analisis lembar jawaban mahasiswa pada tes kemampuan pemecahan masalah dan berpikir kritis menunjukkan berbagai temuan. Mahasiswa yang diberikan pembelajaran $\mathrm{PjBL}$ telah mampu menyelesaikan soal kemampuan pemecahan masalah dan berpikir kritis dengan nilai rata-rata lebih tinggi dari kelas dengan eskpisitori.

Hasil penelitian ini memfokuskan pada kemampuan pemecahan masalah dan berpikir kritis pada level mahasiswa. Beberapa penelitian juga terdahulu dengan subjek siswa tingkat sekolah menengah menunjukkan adanya pengaruh pembelajaran $\mathrm{PjBL}$ terhadap kemampuan pemecahan masalah maupun kemampuan berpikir kritis. Hasil penelitian yang dilakukan oleh Komalasari[11]; Eka, Karyanto, \& Sugiharto [12]; Sularmi, Utomo, \& Ruja [13] menyebutkan model Project Based Learning dapat meningkatkan kemampuan berpikir kritis siswa. Selanjutnya hasil penelitian yang dilakukan oleh Adi, Putu, \& Wayan [14]; Yunarni [15] menunjukkan bahwa model Project Based Learning memiliki pengaruh terhadap kemampuan pemecahan masalah.

\section{KESIMPULAN}

Berdasarkan hasil penelitian dan pembahasan dapat disimpulkan bahwa penerapan model project based learning berpengaruh terhadap kemampuan pemecahan masalah dan berpikir kritis mahasiswa pada pembelajaran statistika dasar. Pengaruh tersebut dengan menerapkan langkah PjBL yang didasarkan yang menunjang pengembangan kemampuan pemecahan masalah dan berpikir kritis mahasiswa

\section{SARAN}

Mencermati hasil dan pembahasan penelitian, maka saran adalah sebagai berikut.

1) Hendaknya dalam pelaksanaan model PjBL dosen dapat menyusun lembar kerja mahasiswa (LKM) sendiri dan menggunakan masalah nyata

2) Dosen hendaknya menyediakan pertanyaan yang relevan dengan tujuan penyampaian materi, sehingga jika pertanyaan tidak muncul dari mahasiswa, Dosen dapat membimbing mahasiswa

3) Dalam penerapan PjBL hendaknya menyiapkan kelompok kecil yang heterogen di awal pembelajaran

\section{DAFTAR PUSTAKA}

[1]Eru, L., U. (2019). Pengaruh model pembelajaran berbasis masalah terhadap kemampuan berpikir kreatif siswa. Jurnal THEOREMS (The Original Research of Mathematics). Vol.4, No.1, pp. 49-59.

[2]Ariawan, R \& Hayatun Nufus, H. (2017). Hubungan Kemampuan Pemecahan Masalah Matematis dengan Kemampuan Komunikasi Matematis Siswa. Jurnal THEOREMS (The Original Research of Mathematics). Vol.1, No.2, pp. 82-91.

[3]Haylock, D. \& Tangatha, F. (2007). Key concepts in teaching primary mathematics. London: Sage Publications

[4]NCTM. (2000). Principles and standarts school mathematics. Reston, Virginia: The National Council of Teachers of Mathematics, Inc

[5]Boss S., \& Krauss, J. (2007). Reinventing project-based learning. Washington DC: ISTE

[6]Filcik, A. et al. (2012). The effects of project-based learning (PjBL) approach on the achievement and 
efficacy of high school mathematics students: a longitudinal study investigating the effects of pjbl approach in mathematics education. Proceedings of The National Conference On Undergraduate Research (NCUR), 29-31 Maret 2012. Odgen Utah: Weber State University, Utah

[7]Ozdemir, E. (2006). An investigation on the effects of project-based learning on students' achievement in and attitude towards geometry. Tesis: tidak dipublikasikan. Middle East Technical University

.[8]Beres, P. J. (2011). Project-based learning and its effect on motivation in the adolescent mathematics classroom., University of New York

[9]Sugiyono. (2013). Metode Penelitian Pendidikan Pendekatan Kuantitatif, Kualitatif, dan RED. Bandung: Alfabeta

[10]Ratnaningsih, N (2007) Pengaruh Pembelajaran Kontekstual Terhadap Kemampuan Berpikir Kritis dan Kreatif Matematik serta Kemandirian Belajar Siswa Sekolah Menengah Atas. UPI Bandung

[11]Komalasari (2018). Pengaruh Model Project Based Learning terhadap Kemampuan Berpikir kritis Siswa pada Pembelajaran IPA di SD. epository.upi.edu

[12]Eka, D, Karyanto,P, \& Sugiharto, B. (2018). Pengaruh Model Project Based Learning (PjBL) terhadap Kemampuan Berpikir Kritis Siswa Kelas X SMA Negeri 2 Karanganyar, BIO-PEDAGOGI, Vol 2 No 2, hlm. 9299

[13]Sularmi, Hari, \& Ruja. (2018). Pengaruh Project-Based Learning terhadap Kemampuan Berpikir Kritis. Jurnal Pendidikan:Vol 3 No 4, Hlm. 475-479

[14]Adi , G., J, Putu, L., P, \& Wayan, R. (2017). Pengaruh model problem based learning (PBL) terhadap kemampuan pemecahan masalah matematika siswa kelas III, e-Journal PGSD Universitas Pendidikan Ganesha Mimbar PGSD Vol: 5 No: 2 Tahun: 2017

[15]Yunarni, A. (2018). pengaruh model pembelajaran problem based learning terhadap kemampuan pemecahan masalah matematika siswa kelas VIIDI SMP Negeri Pangkajene, Jurnal "Mosharafa", Volume 7, Nomor 1, Januari2018, 51-62 